\title{
IN VITRO BIOLOGICAL EVALUATIONS OF THREE-DIMENSIONAL SCAFFOLD DEVELOPED FROM SINGLE-CRYSTAL APATITE FIBRES FOR TISSUE ENGINEERING OF BONE
}

\author{
Mamoru Aizawa*1, Hiroki Shinoda ${ }^{2}$, Hiroshi Uchida ${ }^{2}$, Isao Okada ${ }^{2}$, Takahiko J. Fujimi ${ }^{2}$, \\ Nobuyuki Kanzawa $^{2}$, Hikaru Morisue ${ }^{3}$, Morio Matsumoto ${ }^{3}$, and Yoshiaki Toyama ${ }^{3}$ \\ (* Corresponding author: mamorua@isc.meiji.ac.jp)
}

${ }^{1}$ Department of Industrial Chemistry, School of Science and Technology, Meiji University, 1-1-1 Higashimita, Tama-ku, Kawasaki, 214-8571, Japan

${ }^{2}$ Department of Chemistry, Faculty of Science and Engineering, Sophia University, 7-1 Kioi-cho, Chiyoda-ku, Tokyo, 102-8554, Japan

${ }^{3}$ Department of Orthopedic Surgery, School of Medicine, Keio University, 35 Shinanomachi, Shinjuku-ku, Tokyo, 160-8582, Japan

\begin{abstract}
Single-crystal apatite fibres were synthesized from aqueous solutions in the $\mathrm{Ca}\left(\mathrm{NO}_{3}\right)_{2}-\left(\mathrm{NH}_{4}\right)_{2} \mathrm{HPO}_{4}-\mathrm{HNO}_{3}$ systems by a homogeneous precipitation method using urea. The resulting fibres with long-axis sizes of $60-100 \mu \mathrm{m}$ were composed of carbonate-containing apatite with preferred orientation along the $c$-axis. We have developed porous scaffold for tissue engineering of bone using the single-crystal apatite fibres. The resulting apatite-fibre scaffolds have large pores with diameters of $110-250 \mu \mathrm{m}$ and high porosities of $98-99 \%$. The scaffolds were biologically evaluated using two kinds of cells, osteoblastic cells (MC3T3-E1) and rat bone marrow cells. In both cases, the cells cultured in the scaffolds showed excellent cellular response, such as good cell proliferation and enhanced differentiation into osteoblasts. We conclude that such scaffolds with high porosity and large pore size may be effective as the matrix of tissue engineered structures for promoting regeneration of bone.
\end{abstract}

(Received July 26, 2004; Accepted August 26, 2004)

\section{INTRODUCTION}

Tissue engineering is an important technology that encourages regeneration of the defecting tissue utilizing scaffolds, cells and growth factors. In the case of tissue engineering for bone, porous calcium-phosphate ceramics are generally used as scaffolds, together with bone marrow cells and rhBMP-2 or TGF- $\beta$, as reported by Ogushi and co-workers in detail ${ }^{1}$.

Among the above three factors, the scaffold play a role of three-dimensional (3D) matrices for cells. In general, porous bioceramcis, such as hydroxyapatite $\left(\mathrm{Ca}_{10}\left(\mathrm{PO}_{4}\right)_{6}(\mathrm{OH})_{2} ; \mathrm{HAp}\right)$ and tricalcium phosphate $\left(\mathrm{Ca}_{3}\left(\mathrm{PO}_{4}\right)_{2} ; \mathrm{TCP}\right)$ have been used as a matrix for bone regeneration. Many researchers are trying to develop the high-performance scaffold with high porosity, interconnected pores, and excellent biocompatibility. We are also promoting the development of novel scaffolds using the apatite fibres which are synthesized by a homogeneous precipitation method ${ }^{2-4}$.

One of the bioactive ceramics, HAp, has been widely applied as a biomaterial ${ }^{5}$ and as an adsorbent for chromatography ${ }^{6}$. By controlling the morphology of HAp crystals, novel properties may be produced by enabling controlled orientation of the crystal planes, as HAp crystal has two crystal planes with different charges: positive on the $a(b)$-planes and negative on $c$-planes ${ }^{p}$.

We have successfully synthesized apatite fibre with long axis size of $60-100 \mu \mathrm{m}^{8,9}$. It was confirmed from the results of a high-resolution transmission electron microscopy (HR-TEM) using a shadow imaging technique that the apatite fibres were of single crystals with the $c$-axis orientation parallel to the long axis of the fibre ${ }^{10,11}$.

Selected area electron diffractions (SAED) were performed at five points along the long-axis of the apatite fibre. The diffraction pattern from the five points showed clear spots corresponding to the apatite structure with high crystallinity. As the five diffraction patterns showed the identical features along the long-axis of the fibre, we have concluded that the apatite fibres were not polycrystalline, but single crystals.

The HR-TEM observations combined with the XRD results suggest that the single crystal apatite 


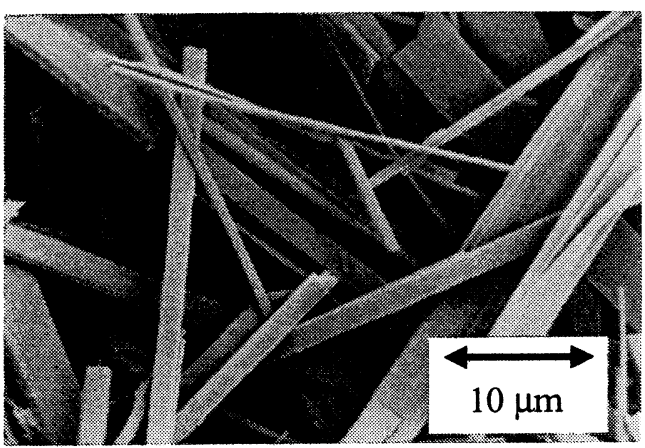

Figure 1 SEM micrograph of the starting apatite fibres.

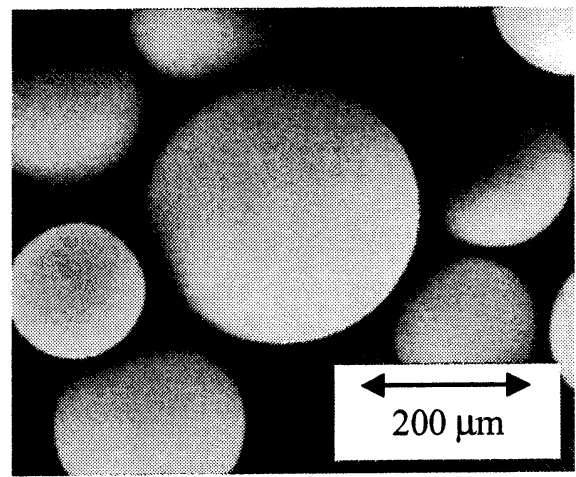

Figure 2 SEM micrograph of the starting carbon beads.

fibres may grow along the $c$-axis to develop the $a(b)$-plane of the hexagonal HAp. Thus, the present apatite fibres may have a positive charge on the surface.

Using the above fibres, we have promoted the development of i) porous HAp ceramics with well-controlled pore sizes ${ }^{8,12}$ and ii) HAp/polymer hybrids possessing mechanical properties similar to those of living cortical bone by in situ bulk polymerization of the monomer in the pores of the ceramic $^{13}$. This hybrid, with mechanical properties similar to those of cortical bone, has been shown to have excellent biocompatibility both in vitro and in vivo ${ }^{14,15}$

In addition, a 3D scaffold for tissue engineering of bone has been developed from the above-mentioned apatite fibres ${ }^{2,16}$. It has already been found that the apatite-fibre scaffold (AFS) has an excellent cellular response, such as enhanced allkaline phosphatase (ALP) activity. However, the pore size is too small to culture the cells three-dimensionally.

In order to enlarge the pore size of the AFS, we have partly modified the fabrication process using carbon beads of about $150 \mu \mathrm{m}$ in diameter as pore forming agents. Thus, we have successfully fabricated the AFS with large interconnected pores of

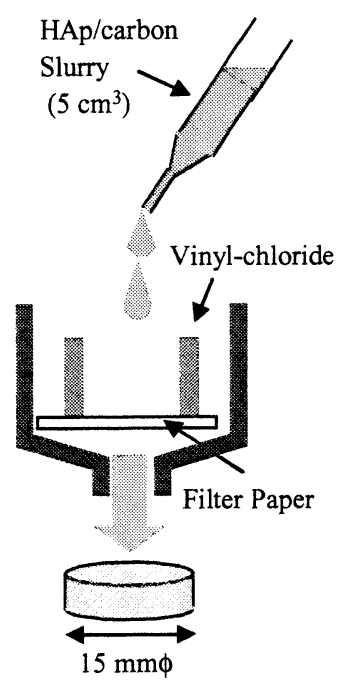

Figure 3 Fabrication process of the green compacts for scaffolds.

$100-250 \mu \mathrm{m}$ in diameter and high porosities of $98-99 \%{ }^{4}$.

However, we have not yet clarified the interactions of the 3D AFSs with osteoblasts. The main purpose of the present investigation was to evaluate the biological properties using two kinds of cells, that is, MC3T3-E1 of an osteblastic cell line and the rat bone morrow cell (RBMC) as a mesenchymal stem cell model. We examined the cellular responses to AFSs: cell attachment, proliferation, differentiation (assays and gene expression of differentiation makers of the osteoblasts), and morphology.

\section{EXPERIMENTAL METHODS}

Fabrication process of apatite-fibre scaffold and its characterisation.

The HAp fibres were prepared from aqueous solutions in the $\mathrm{Ca}\left(\mathrm{NO}_{3}\right)_{2}-\left(\mathrm{NH}_{4}\right)_{2} \mathrm{HPO}_{4}-\left(\mathrm{NH}_{2}\right)_{2} \mathrm{CO}-$ $\mathrm{HNO}_{3}$ system through a homogeneous precipitation method using urea, as previously reported ${ }^{8}$. The HAp fibres were suspended with spherical carbon beads (Nika beads; Nihon Carbon Company) with a diameter of $\sim 150 \mu \mathrm{m}$ in the mixed solvent (ethanol $/$ water $=1 / 1(\mathrm{v} / \mathrm{v})$ ). The carbon beads were added to the HAp fibre in the following carbon/HAp $(\mathrm{w} / \mathrm{w})$ ratios: $20 / 1,10 / 1,1 / 1$ and $0 / 1$. Figure 1 and 2 show the particle morphologies of apatite fibres and carbon beads used as starting materials, respectively.

The green compacts for the scaffold were fabricated by pouring and vacuum pumping the above mixed suspension containing $\sim 1$ mass $\%$ of the HAp $\left(5 \mathrm{~cm}^{3}\right)$ into the vinyl-chloride mould of $16.5 \mathrm{~mm}$ in internal diameter as drawn in Fig. 3. The resulting 


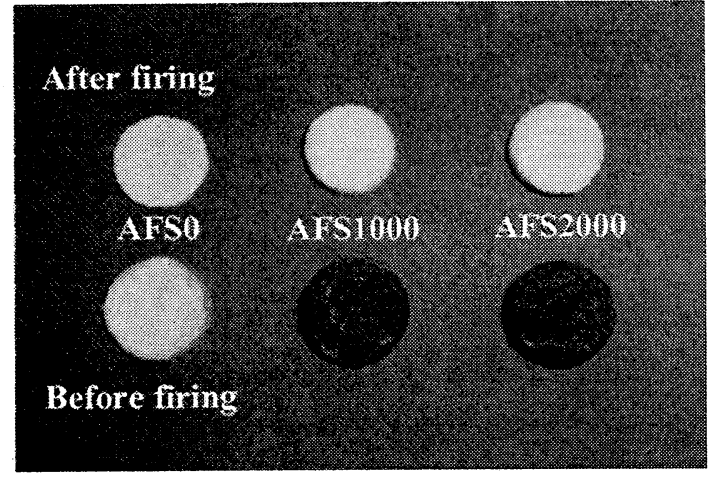

Figure 4 Overview of scaffolds before and after firing.

compacts were fired at $1300^{\circ} \mathrm{C}$ for $5 \mathrm{~h}$ in a steam atmosphere to develop the structure of the scaffold. Figure 4 shows the overview of each scaffold before and after firing. Hereafter, we name the scaffolds derived from carbon/HAp $=20 / 1,10 / 1$ and $0 / 1(\mathrm{w} / \mathrm{w})$ "AFS2000", "AFS1000" and "AFS0", respectively.

The resulting scaffolds were characterized as follows: i) phase identification by X-ray diffractometry (XRD) and infrared spectroscopy (IR), ii) observation of microstructure by scanning electron microscopy (SEM), iii) examination of pore size distribution by mercury porosimetry and iv) measurement of porosity on the basis of the mass and dimension of the scaffolds.

\section{Biological evaluation of apatite fibre scaffold using} osteoblastic cells

\section{1) MC3T3-E1 cells}

The resulting scaffolds were biologically evaluated using osteoblastic cells, MC3T3-E1 ${ }^{\text {I7 }}$. The cellular responses to the three kinds of scaffolds, AFS0, AFS 1000 and AFS2000, were examined by observing i) the initial cell-attachment efficiency after seeding for $5 \mathrm{~h}$, ii) the cell proliferation during 1 to $21 \mathrm{~d}$, iii) gene expressions of differentiation makers of osteoblasts ( 7 and $21 \mathrm{~d}$ ), iv) the cell morphology.

Five hundred thousand cells were seeded on each scaffold and cultured for the desired period of time. The medium used was $\alpha$-minimum essential medium $(\alpha$-MEM) with $10 \%$ fetal bovine serum (FBS) (Gibco $\mathrm{BRL}$ ); culture conditions were at $37^{\circ} \mathrm{C}$ in a $5 \% \mathrm{CO}_{2}$ atmosphere.

As for initial cell-attachment efficiency and proliferation, the DNA contents in the cell cultured with 3D scaffolds were measured instead of usual cell-counting. DNA contents were determined using the Hoechst 33258 method. Cell morphology was observed using SEM after fixation by a $10 \%$ gultaraldhyde solution at $4{ }^{\circ} \mathrm{C}$ for $1 \mathrm{~h}$.
Gene expressions of the cell cultured with AFSs were examined by the reverse-transcription polymerase chain reaction (RT-PCR) method (7, 21 d). Total RNA of the cells was extracted using TRIZOL ${ }^{\circledR}$ (Gibco BRL) regent. Complementary DNA (cDNA) was prepared by reverse transcription of the mRNA. Expression of differentiation maker genes of osteoblasts were examined by electrophoresis of the PCR products obtained from the reactions of cDNA with some primers. Used primers were “F: 5'-TCTCAACTCTTCTAGT TCCT-3, R: 5'-TTGGGTCATTTCCACATGC-3' for I-collagen (I-col), "F: 5'-TACCGACCCTGTTC TGAGGG-3', R: 5'-ACCCTGGGTAGACAGCCA A-3"” for ALP, "F: 5'-ACACTTTCACTCCAATCG TCC-3', R: 5'-TGCCCTTTCCGTTGTTGTCC-3"' for osteopontin (OP), and "F: 5'-GGAACGGTTTC CAGTCCAG-3', R: 5'-TGAAACCCGTTCAGAA GG-3" for bone sialoprotein (BSP).

\section{2) Rat bone marrow cells (RBMC)}

The resulting scaffolds were also biologically evaluated using bone marrow cells derived from the wistar rats ( 4 weeks old, male), as reported by Maniatopoulos et al. ${ }^{18}$. In the RBMC cases, the cell differentiation and calcification were especially examined. The contents of the ALP and osteocalcin (OCN) in the cell cultured with AFSs were determined for clarifying the stages of cell differentiation. The behaviour of the calcification was also examined by use of alizarin red stain.

Five hundred thousand cells were seeded on each scaffold and cultured for the desired period of time. The medium used was $\alpha$-MEM with $10 \%$ FBS containing $10 \mathrm{nM}$ dexamethazone, $200 \mu \mathrm{M}$ ascolbic acid and $1 \mathrm{mM} \beta$-sodium glycerophosphate; culture conditions were $37{ }^{\circ} \mathrm{C}$ in a $5 \% \mathrm{CO}_{2}$ atmosphere.

The ALP activity was determined by normalizing for DNA content in the cell cultured as an early stage of osteoblast differentiation. The ALP assays were measured using a kit of Wako chemicals based on the Bessey-Lowry method and polystyrene plate for cell culture was used as a control.

The OCN contents were also determined by normalizing for DNA content as the last stage of osteoblast differentiation. OCN assays were measured using a kit of Takara based on the ELIZA method and polystyrene plate for cell culture was used as a control.

\section{RESULTS AND DISCUSSION}

Some properties of the apatite-fibre scaffolds for 3D-cell culture

Table 1 shows the preparation conditions of typical scaffolds and their porosity and median pore size. Single HAp phase was present in the resulting scaffolds regardless of carbon-bead addition. The 
Table 1 Some properties of the scaffolds.

\begin{tabular}{|c|c|c|c|}
\hline $\begin{array}{l}\text { Sample } \\
\text { name }\end{array}$ & $\begin{array}{c}\text { Carbon/HAp } \\
{[w / w]}\end{array}$ & $\begin{array}{c}\text { Porosity } 1 \\
{[\%]}\end{array}$ & $\begin{array}{l}\text { Median pore } \\
\text { size }[\mu \mathrm{m}]\end{array}$ \\
\hline AFS0 & $0 / 1$ & $94 \pm 0.5$ & 5.2 \\
\hline AFS1000 & $10 / 1$ & $98 \pm 0.1$ & 112.8 \\
\hline AFS2000 & $20 / 1$ & $99 \pm 0.1$ & 247.3 \\
\hline
\end{tabular}

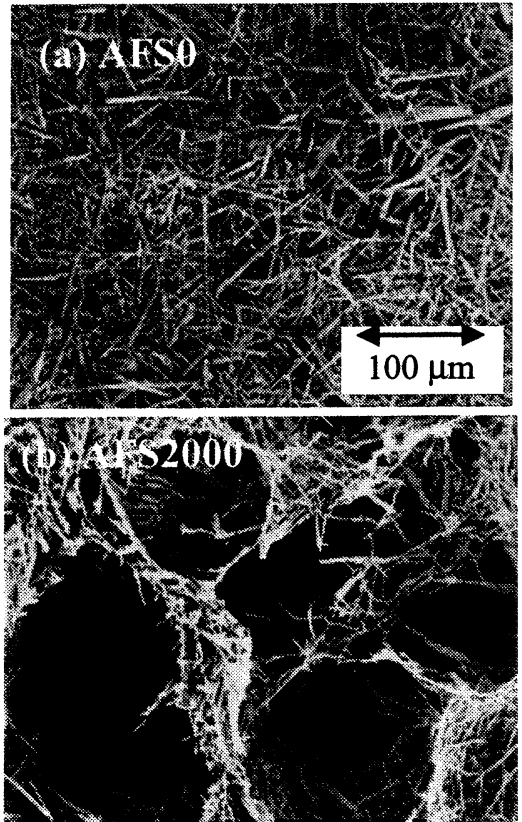

Figure 5 Microstructure of the scaffolds: (a) AFS0 and (b) AFS2000.

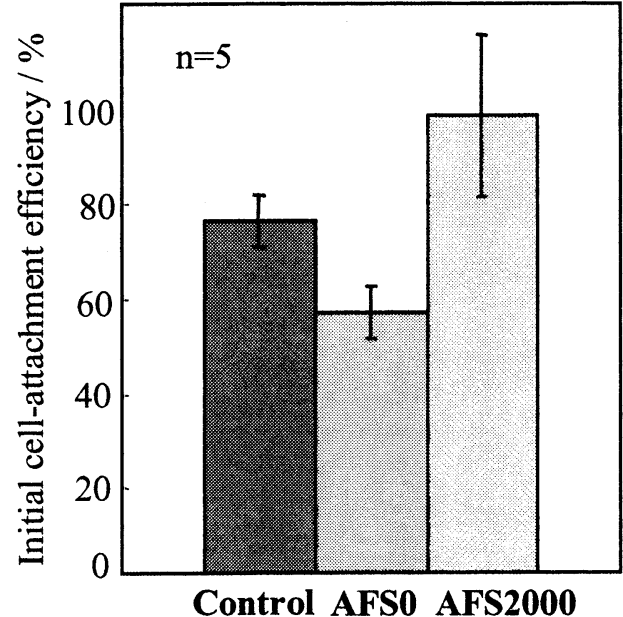

Figure 6 Initial cell-attachment efficiency of cells seeded on scaffolds.

pore sizes are listed in Table 1. In the case of the AFS0 scaffold, the pore size distribution was very limited; in the range of about $5 \mu \mathrm{m}$. On the other hand, the pore size distribution of the AFS2000 scaffold shifted toward larger pore sizes, that is, in the range of $100-500 \mu \mathrm{m}$.

In fact, the median pore sizes of the AFS0, AFS1000 and AFS2000 scaffolds were 5.2, 112.8 and $247.3 \mu \mathrm{m}$, respectively. These large pores were generated by releasing the carbon beads during firing. The AFS 1000 and AFS2000 scaffolds developed using the carbon beads, had a large pore size and high porosity, as compared to the carbon-free derived scaffold (AFS0). In particular, the AFS2000 scaffold may contain pores of dimensions suitable for cell in-growth.

HAp had preferred orientation in the (h00) planes: (100), (200) and (300). The porosities of the apatite-fibre scaffolds increased from $\sim 94 \%$ to $\sim 99 \%$ as the volume fraction of carbon beads was increased.

Figure 5 shows the microstructure of the AFS0 (Fig. 5(a)) and AFS2000 (Fig. 5(b)) scaffolds prepared from the experimental conditions of carbon $/$ HAp $=0 / 1$ and 20/1 [w/w]. SEM observation showed that the AFS2000 scaffold was composed of large pores of $100-300 \mu \mathrm{m}$ in diameter and smaller pores formed by intertwining of individual fibres and that the pores were interconnected in the structure. As compared with microstructure of the carbon-free derived scaffold (AFS0), the pore sizes of the scaffolds, AFS1000 and AFS2000, were significantly enlarged with increasing amounts of the carbon beads added.

The pore-size distribution of the scaffolds was measured using a mercury porosimeter. The median

\section{In vitro biological evaluation of apatite-fibre scaffolds}

We firstly performed a biological evaluation using MC3T3-E1 cells in order to identify the cell-toxicity of the resulting scaffolds. The AFS0 and AFS2000 were used as the samples in this investigation, as well as a polystyrene control.

\section{1) Initial cell-attachment efficiency}

Figure 6 shows the results of initial cell-attachment efficiency. The efficiencies cultured on/in the scaffolds after $5 \mathrm{~h}$ of cell culture, were $74.2 \pm 1.5 \%$ for the control, $55.0 \pm 1.9 \%$ for the AFS0 and $96.2 \pm 4.5 \%$ for the AFS2000. These results could be regarded as significant $(P<0.05)$ by an analysis of valence (ANOVA); the initial cell-attachment efficiencies of the AFS2000 showed the highest value among the tested samples. 
Aizawa M, Shinoda H, Uchida H, Okada I, Fujimi TJ, Kanzawa N, Morisue H, Matsumoto M, Toyama Y

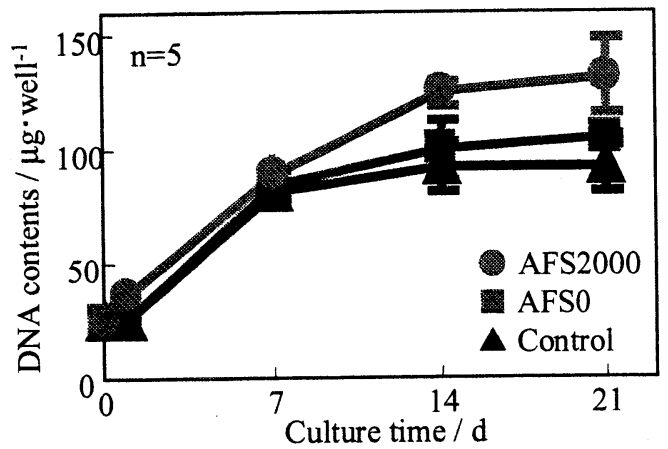

Figure 7 Proliferation of cells cultured in/on the scaffolds.
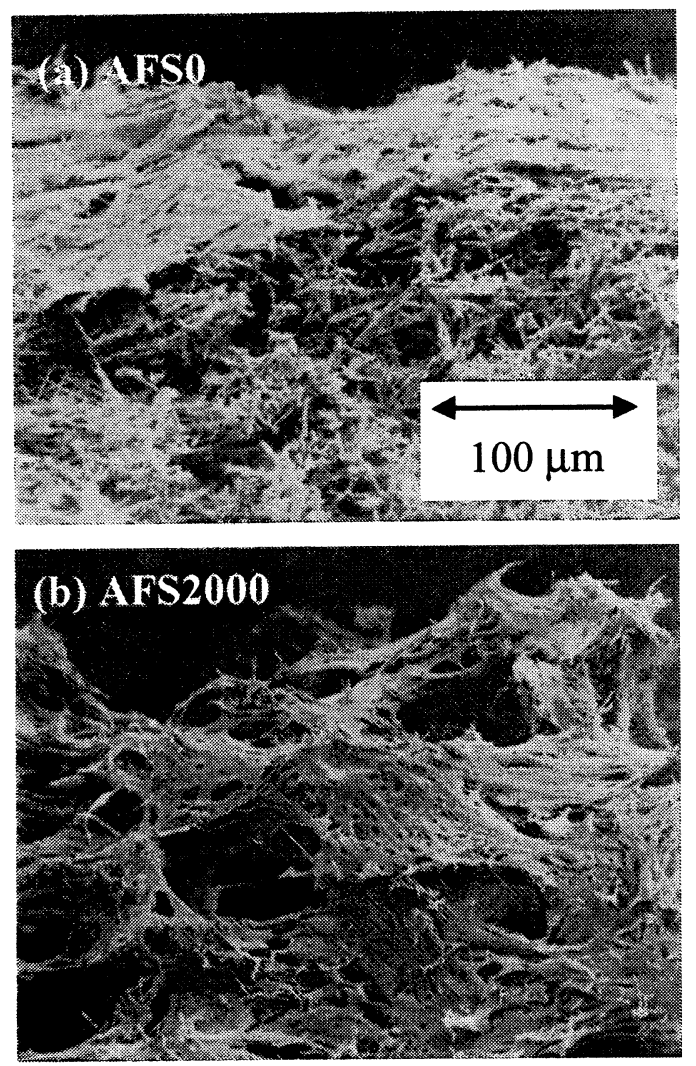

Figure 8 Morphologies of cells cultured in/on the scaffolds for 21 days (cross section) : (a) AFS0 and (b) AFS2000.

\section{2) Cell proliferation}

Figure 7 shows the growth curves of the cells seeded on these three kinds of sample. The cells in the AFS2000 proliferated in a similar manner to those on the control and the AFS0 during the incubating periods from $1 \mathrm{~d}$ up to $7 \mathrm{~d}$. However, the cells in the AFS2000 proliferated more than those in the AFS0 and on the control after the long incubating periods of $7 \mathrm{~d}$ to $21 \mathrm{~d}$. These results could be regarded as significant $(P<0.05)$ by the ANOVA. The present

\begin{tabular}{|c|c|c|c|}
\hline Sample & Control & AFS0 & AFS2000 \\
\hline Time / d & 721 & 721 & 721 \\
\hline I-col & & & \\
\hline ALP & & & \\
\hline OP & & & \\
\hline BSP & & & \\
\hline Actin & & & \\
\hline
\end{tabular}

Figure 9 Gene expression of the specific proteins of the cells cultured in/on the scaffolds using actin as a control.

good cell proliferation results may be due to the $3 \mathrm{D}$ structure of the AFS2000.

The SEM observation of the cells cultured for $21 \mathrm{~d}$ revealed that the AFS2000 scaffold was able to support 3D cell proliferation more efficiency, compared with AFS0 (Fig. 8). It could be seen from in vitro evaluation using an osteoblastic cell line, that the above-mentioned scaffolds had an excellent cellular response, including good initial cell-attachment efficiency and subsequent proliferation.

\section{3) Gene expressions}

We performed an analysis of the gene expression using an RT-PCR method. Although the specific proteins are well-known as the differentiation markers of the osteoblast, we chose the four proteins: I-Col, ALP, OPN and BSP. The results are shown in Fig. 9. In the case of AFS2000, the amplified fragment of ALP cDNA was observed after culture for $7 \mathrm{~d}$, and then that of the BSP after culture for $21 \mathrm{~d}$, although the latter band was not clear. This finding reveals that AFS2000 will promote the differentiation of osteoblast.

\section{4) Assay of ALP activity}

Biological evaluation using rat bone marrow cells was next performed to examine the differentiation of the cells into osteoblasts and subsequent calcification leading to bone regeneration. The samples used were the same as for the MC3T3-E1 cell test.

Figure 10 shows the ALP activity normalized for the DNA content of the cells cultured on/in scaffolds for 7, 14 and $28 \mathrm{~d}$. The ALP activities of the cells cultured on the control, AFS0 and AFS2000 scaffolds for $7 \mathrm{~d}$ were $5.8 \pm 0.2,6.2 \pm 0.2$ and $11.5 \pm 0.4 \mathrm{IU} /$ $\left(\mathrm{dm}^{3} \cdot \mu \mathrm{gDNA}\right)$, respectively, at $37^{\circ} \mathrm{C}$. The ALP 


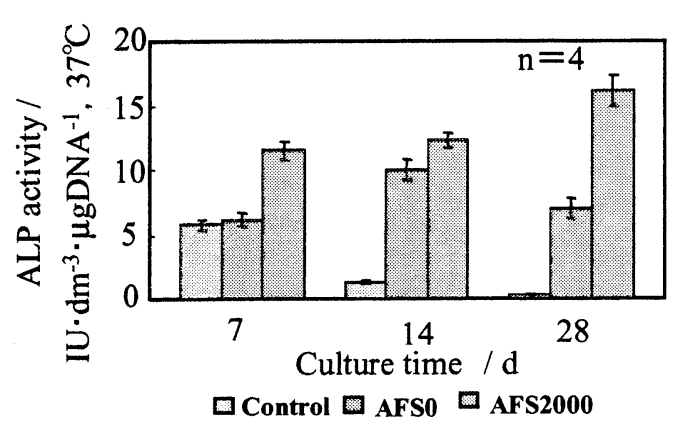

Figure 10 ALP activity normalized for DNA content of the cells cultured in/on the scaffolds.

activity of the AFS2000 showed the highest value amongst the tested samples. These results could be regarded as significant $(P<0.05)$ by ANOVA. The ALP activity of the cells cultured on the control decreased at 14 and $21 \mathrm{~d}$. Although the ALP activity of the cells cultured in the AFS0 attained the maximum value at $14 \mathrm{~d}$, the value decreased at $21 \mathrm{~d}$. In the case of the AFS2000, the ALP activity increased with longer incubating periods. This may be the reason why the AFS2000 scaffold with high porosity and large pore size provided the most suitable environment for enhancing bone marrow cell activity.

\section{4) Assay of $\mathrm{OCN}$ contents}

We have determined contents of the OCN normalized for the DNA content (Fig.11). The OCN contents of the cells cultured in/on the control, AFS0, AFS1000 and S2000 for $28 \mathrm{~d}$ were $2.0 \pm 0.1,1.9 \pm$ $0.1,3.0 \pm 0.1$ and $3.4 \pm 0.3 \mu \mathrm{g} / \mu \mathrm{gDNA}$, respectively. These findings that the AFS2000 has given the best result with respect to all the tests demonstrate that the high porosity and large pore size fulfilled by the AFS2000 could provide an excellent environment for enhancing bone marrow cell activity.

In addition, it was found from the results of the alizarin red staining that the calcification of the bone marrow cells commenced at $\sim 7 \mathrm{~d}$ and that this calcification area grew right up to $\sim 28 \mathrm{~d}$. Although the mechanical strength of the present AFS2000 is relatively weak, it is sufficient for our cell-culture operations. The strength of the AFS2000 was, however, enhanced after calcification of the bone-marrow cells, allowing them to form a bone-like structure.

Based on the above findings for cell proliferation and differentiation, we can conclude that the present apatite-fibre scaffold has excellent cellular responses and biocompatibility. This may be due to the following reasons: (i) presence of $a(b)$-plane developed by $c$-axis orientation of apatite fibres, (ii)

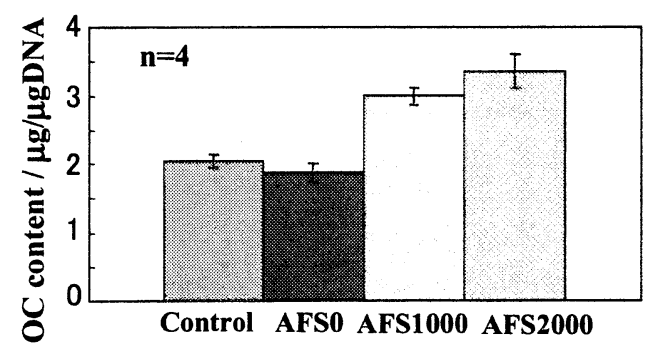

Figure 11 OCN contents normalized for DNA content of the cells cultured for $28 \mathrm{~d}$ in/on the scaffolds.

carbonate-containing apatite, and (iii) 3D-structured apatite-fibre scaffold. We have a plan to perform a further investigation.

\section{CONCLUSIONS}

Novel scaffolds for tissue engineering for bone has been developed from single-crystal apatite fibres synthesized by a homogeneous precipitation method using urea. The resulting apatite-fibre scaffolds have large pores of $110-250 \mu \mathrm{m}$ in diameter and high porosities of $98-99 \%$. The scaffolds were biologically evaluated using two kinds of cells, osteoblastic cell (MC3T3-E1) and rat bone marrow cells. In both cases, the cells cultured on/in the scaffolds showed excellent cellular responses, such as good initial cell-attachment efficiency, good cell proliferation and enhanced differentiation into osteoblasts. The AFS2000 scaffold was particularly able to support $3 \mathrm{D}$ cell proliferation. The bone marrow cells cultured in the scaffold were calcified creating a bone-like structure. It can be concluded that the AFS2000 scaffolds with high porosity and large pore size may be effective as the matrix for tissue engineering leading to bone regeneration.

\section{ACKNOWLEDGEMENT}

The authors appreciate Dr. K. Yamashita in the Tokuyama University for helps of primer design of MC3T3-E1 cells. The present investigation has been supported by the Industrial Technology Research Grant Program in 2002-04 from NEDO.

\section{REFERENCES}

1. H. Ogushi, J. Jpn. Soc. Biomater., 20, 296-304 (2002).

2. M. Aizawa, H. Ueno, K. Itatani, Material Integration, 12, 75-77 (1999). 
Aizawa M, Shinoda H, Uchida H, Okada I, Fujimi TJ, Kanzawa N, Morisue H, Matsumoto M, Toyama Y

3. M. Aizawa, (2001) Japan patent: tokugann 2001-300791.

4. M. Aizawa, H. Hiroki, H. Uchida, K. Itatani, I. Okada, M. Matsumoto, H. Morisue, H. Matsumoto, Y. Toyama, Key Engineering Materials, 240-242, 647-650 (2003).

5. L. L. Hench, J. Am Ceram. Soc., 81, 1705-28 (1998).

6. K. Ota, H. Monma and T. Kawasaki, Inorg. Mater., 6, 224-30 (1999).

7. T. Kawasaki, J. Chromatogr., 544, 147-84 (1991).

8. M. Aizawa, F. S. Howell, K. Itatani, Y. Yokogawa, K. Nishizawa, M. Toriyama and T. Kameyama, J. Ceram. Soc. Jpn., 108, 249-253 (2000).

9. M. Aizawa, T. Terado, F. S. Howell and K. Itatani, Mater. Res. Bull., 34, 1215-25 (1999).

10. M. Aizawa, A. E. Porter, S. M. Best and W. Bonfield, Key Engineering Materials, 240-242, 509-512 (2003).

11. M. Aizawa , A. Porter, S. Best and W. Bonfield, Key Engineer. Mater, 254-256, 915-918(2004).

12. M. Kawata, H. Uchida, K. Itatani, I. Okada, S. Koda and M. Aizawa, J. Mater. Sci: Mater. Med., 15, 817-823(2004).

13. M. Aizawa, Y. Tsuchiya, K. Itatani, H. Suemasu, A. Nozue and I. Okada, Bioceramics, 12, 453-456 (1999).

14. M. Aizawa, M. Ito, K. Itatani, H. Suemasu, A. Nozue, I. Okada, M. Matsumoto, M. Ishikawa, H. Matsumoto and Y. Toyama, Key Engineering Materials, 218-220, 465-468 (2002).

15. M. Aizawa, M. Ito, K. Itatani, I. Okada and M. Matsumoto, Phosphorus letters, No. 46, 7-14 (2003).

16. M. Aizawa, H. Ueno and I. Okada, Trans. Mater. Res. Soc. Jpn., 28, 849-852(2003).

17. H. Sudo, H. Kodama, Y. Amagai, S. Yamamoto and S. Kasai, J. Cell Biol., 96, 191 (1983).

18. C. Maniatopoulos, J. Sodek and A. H. Melcher, Cell Tissue Res., 254, 317-330(1988). 